\title{
My history, your history, our history: Developing meaningful community engagement within historic sites and museums
}

\author{
Jessica Stroja \\ jessica.stroja@griffithuni.edu.au
}

\begin{abstract}
Varying models of community engagement provide methods for museums to build valuable relationships with communities. These relationships hold the potential to become ongoing, dynamic opportunities for active community participation and engagement with museums. Nevertheless, the nuances of this engagement continue to remain a unique process that requires delicate balancing of museum obligations and community needs in order to ensure meaningful outcomes are achieved. This article discusses how community engagement can be an active, participatory process for visitors to museums. Research projects that utilise aspects of community-driven engagement models allow museums to encourage a sense of ownership and active participation with the museum. Indeed museums can balance obligations of education and representation of the past with long-term, meaningful community needs via projects that utilise aspects of community-driven engagement models. Using an oral history project at Historic Ormiston House as a case study, ${ }^{1}$ the article argues that museums and historic sites can encourage ongoing engagement through active community participation in museum projects. While this approach carries both challenges and opportunities for the museum, it opens doors to meaningful and long-term community engagement, allowing visitors to embrace the museum and its stories as active participants rather than as passive consumers.
\end{abstract}

\section{Introduction}

Opening the visitor book, a group of volunteers who were cataloguing items into a research library and archive could see the handwriting and thoughts of the many people who had passed through the doors of Historic Ormiston House, an historic house museum located approximately forty minutes from the Brisbane CBD. The book had captured these tiny moments in time, when visitors to this historic house had stopped to share their thoughts about their visit. A visitor book had always 
been available to guests who visited the historic property, placed in the foyer of the grand historic home. Members of the public were invited to leave their thoughts and impressions in the visitor book before stepping out of the house and its sense of yesteryear, and back into the present time.

There were similar books, also filled with writing and guests' impressions of the house, on the shelf in a room that had once been a bedroom, but was now converted to a research library and reading room. Each book told a story of visitors from all over the world who were visiting Queensland and had made their way to this historic home on the edge of Moreton Bay. Significant research, time, fundraising and work by volunteers had contributed to the development of Historic Ormiston House from a private residence into an historic house museum, open to the public. 'Thank you devoted volunteers', 'keep restoration going', 'beautifully kept' were all messages received by the public, recorded in the book these volunteers were now reading more than a decade since these words had been written by guests, and more than half a century since the restoration of this beautiful home had first commenced. $^{2}$

Historic Ormiston House is a fourteen-room house located in the suburb of Ormiston, in Redland City. A privately owned property, the historic house and its accompanying grounds and gardens are open to the public as an historic house museum. Other historic buildings on the property include a large two-roomed slab hut and saddlery, a two-room brick building (which now houses amenities) and a cottage (currently a private residence that is not open to the public). A monastery and chapel were also constructed on the property by the present owners (the Corporation of Discalced Nuns of The Order of Our Lady of Mount Carmel, hereafter the 'Carmelite Community') after they purchased the property. ${ }^{3}$ Shortly after the property was purchased by the Carmelite Community, efforts to restore the historic house and convert it into an historic house museum commenced.

The idea of restoring Ormiston House was first developed in 1965 when two retired businesswomen attended an open air mass in the grounds of Ormiston House to mark the Cloistering Day for the Carmelite Monastery. ${ }^{4}$ It was during this visit to the property that they saw 'the potential for restoring Ormiston House' and after consultation with the Carmelite Community, volunteer-run restoration efforts commenced. ${ }^{5}$ Over time, the team of volunteers contributing to these efforts grew, and various milestones were achieved. An understanding of the history of the property had been established, and each of the rooms had gradually been furnished. Visitor numbers to the property had continued to increase dramatically since it had first been opened to the public, and the quantity of bookings had increased each year. ${ }^{6}$

As a volunteer-run, not-for-profit organisation, Historic Ormiston House was considered successful. The organisation and its volunteers had been recognised for their restoration efforts and contributions to Redlands tourism for many years via tourism industry awards, ${ }^{7}$ yet the volunteers who oversaw Historic Ormiston House desired a deeper meaning for the property as an historic house museum. The volunteers who were dedicated to ensuring the ongoing restoration and maintenance of the property wanted to ensure that the property would become increasingly relevant to visitors and the community. In so doing it was hoped the property would become more than a static historic display, frozen in time, but could instead become a place where guests could actively engage with Historic Ormiston House, rather than passively viewing and consuming displays. Efforts to ensure that 
positive steps were taken towards this goal led to the consideration of museum engagement principles and practices at Historic Ormiston House. A variety of proactive steps were undertaken to transform Historic Ormiston House from a series of rooms displaying information to the public into an historic site that actively encouraged its visitors to engage with the property and its history. This article presents one aspect of these engagement processes undertaken at Historic Ormiston House, and provides the opportunity to analyse how a research project can facilitate engagement and provide benefits to both a museum and its community.

The goal of community engagement is becoming increasingly relevant to museums, as traditional museums and other historic sites attempt to remain relevant in a rapidly changing landscape. Within both traditional museums and historic house museums (HHM), the process of engagement involves many individuals, from museum management, daily staff and volunteers through to the community itself. Indeed, community engagement is a complex, multi-layered process that can provide benefits to both the museum and the community. ${ }^{8}$ These benefits can be far reaching, and can include impacts on the museum itself, as well as social and cognitive benefits for visitors. ${ }^{9}$ This process requires a delicate balancing of museum obligations and community needs, including consideration of the unique context of each individual museum or HHM. Nonetheless, despite the challenges that can be present when negotiating the processes of museum engagement, the opportunities present throughout this process have been receiving increased attention from museum professionals. ${ }^{10}$

The possibilities of museum engagement are widespread, and there are many benefits that can arise as a result of positive, participatory engagement in museums. ${ }^{11}$ A wide range of definitions of museum engagement exist, from explanations that define engagement as a seemingly straightforward process of attracting the attention of the public to more intricate understandings that acknowledge museums, communities and engagement as 'complex networks or assemblages of people, materials and ideas'. ${ }^{12}$ While the varying definitions of engagement and what constitutes this process each hold their own challenges and opportunities, this article considers positive, ongoing museum engagement to be engagement with visitors that continues over an extended period, and results in reciprocal relationships that benefit both the museum and its visitors. ${ }^{13}$ An analysis of one method used within the engagement process at Historic Ormiston House reveals that, while much extant literature addresses engagement within traditional museum spaces, the possibilities of engagement apply both to these traditional spaces and to historic house museums.

Museums and other historic sites face numerous unique challenges throughout day-to-day operation. While in some locations museums are deeply integrated into community life and learning, in others museums and historic sites are facing a decline in the perceived importance of historic landmarks and museums. ${ }^{14}$ As interest in historic sites seemingly diminishes, attempts to increase community engagement are employed to increase the relevancy of historic sites in a changing landscape. Statistics and other quantifying factors are utilised to determine the success of museum projects and engagement. ${ }^{15}$ Yet engagement is much more than numbers of visitors or increased revenue. As Amareswar Galla suggests, museum engagement and inclusivity open the doors to increased opportunities and benefits for communities, turning museums and historic sites into 'aspirational space[s] that [are] created and recreated based on the context and relevance to multiple 
stakeholders' ${ }^{16}$ The creation and recreation of sites to which Galla refers is a particularly beneficial understanding for historic house museums such as HHM, as the situation of the historic house museum and its visitors is unique and does not conform to the typical requirements and scenarios facing traditional museums.

These 'aspirational spaces', created through the processes of engagement, allow museums to consider their unique role within the landscape as one that is rapidly changing. Indeed, the idea that museums can deliver on project targets and outcomes while still encouraging beneficial community outcomes is becoming more widely accepted. ${ }^{17}$ The balance of museum obligations and goals with community needs and desires is crucial to museums that exist within a rapidly changing society. At Historic Ormiston House, the organisation's relationship with the community functions as part of a multi-layered approach to engagement, which ensures that a variety of methods and practices are undertaken to ensure positive engagement. In addition to ensuring the practical aspects of engagement, research projects are actively developed at Historic Ormiston House in order to help nurture relationships between Historic Ormiston House and the community. As a completely volunteer-run organisation, Historic Ormiston House must carefully balance its obligations and commitments as an historic site with the needs of the local and wider community. This article presents one aspect of the engagement processes at Historic Ormiston House, and provides the opportunity to analyse how a research project can facilitate engagement and provide benefits to both a museum and its community.

\section{Historic house museums: Engagement, visitors and a desire to be relevant}

Historic house museums share various similarities with traditional museum spaces; however, they retain a unique identity within the heritage landscape. For many years, historic house museums have been known 'to be among the smallest museums in terms of staff and budget ... [and many] are run entirely by volunteers', operating with only 'minimal resources'. ${ }^{18}$ Traditionally, many such historic house museums documented the life of a particular figure or group of people in society (documentary HHM), while some served to represent 'a particular style of architecture from a particular period' (representative HHM) and others housed collections of 'decorative and fine arts, furniture, and antiques' (aesthetic HHM). ${ }^{19}$ The functions of historic house museums today largely fall into similar categories, and a variety of displays and events are often held in order to 'inform the visitor about the past' while 'raise[ing] funds to maintain the site and keep it open' ${ }^{20}$ It has nonetheless been recognised that HHM 'must become more central to community life by inviting people to actively engage as cultural participants, not passive consumers'. ${ }^{21}$

Historic house museums face unique challenges that must navigated if they are to remain viable historic sites. The introduction of new technologies, such as the use of the internet and digital media within the museum sector, has impacted the position of many HHM that are now 'struggling for relevancy'. ${ }^{22}$ Many challenges faced also present themselves as a result of the intrinsic nature of historic house museums. ${ }^{23}$ As Linda Young suggests, '[h]ouse museums are almost never 
developed in response to a customer focus. Rather, they exist in a genteel miasma of expectation that audiences will recognize the virtues of house museum visiting and will naturally want to be enlightened and educated by exposure to their fascinating histories. ${ }^{24}$ When compounded by issues of changing demographics, funding, staffing, age of the historic house museum, security and conservation, HHMs find themselves facing 'the need to be relevant to the contemporary world', while also recognising that the 'needs of the society and civic engagement need to be taken into consideration'. ${ }^{25}$

This does not necessarily mean that historic house museums are destined for insignificance in a rapidly changing society; however, it does highlight the increasing importance of museum engagement for HHMs that wish to become (and remain) relevant to communities. Indeed, the question of museum engagement is garnering increasing attention as museums seek to become relevant in a rapidly changing society. While often associated with the traditional museum, engagement and its related processes apply equally to other historic sites, including HHMs, where the consideration of engagement is becoming crucial to daily management and operation. This 'engagement' exceeds measures related to marketing, accessibility, availability or policy reviews and changes. While each of these factors is nonetheless crucial for a museum or historic house museum that wishes to remain relevant and inclusive to the public, inclusion of these factors does not lead to an automatic assurance of engagement. ${ }^{26}$ The processes and practice of engagement must become an active part of HHM management and operation in order to develop and maintain ongoing relevance to communities.

While a substantial body of research surrounding museum studies exists, this scholarship reveals a significantly greater focus on traditional museums rather than historic house museums. ${ }^{27}$ Nonetheless, recognition of historic house museums as a distinct type of historic site with unique characteristics, challenges and opportunities is growing. ${ }^{28}$ Much of this literature relates to the interpretation of historic house museums, the development of houses into historic house museums or the physical difficulties faced in managing an HHM. ${ }^{29}$ Nonetheless, despite the burgeoning interest in the historic house museum, extant literature still leaves many aspects of these unique historic sites unaddressed - such as issues surrounding staffing, funding and significance. The process of engagement within traditional museums has been gaining attention at a rapid rate and, similarly, this process is beginning to gain attention specifically within the context of historic house museums as these organisations seek to increase their relevance and productivity. It is imperative that, as interest in engagement within HHMs grows, the unique context of HHMs is acknowledged and employed throughout the engagement process.

While the current body of knowledge within museum studies does address engagement within historic house museums, a unique perspective is required if this process is to be both successful and beneficial to the HHM and the public. Currently, engagement is frequently considered within the context of museum project outcomes, and the relationship of these outcomes to overall engagement. ${ }^{30}$ In so doing, research project outcomes are considered to be of the greatest significance, and project processes are not considered to be an active part of the engagement process. In contrast, this article suggests that engagement within HHMs must be treated as a functional, ongoing process throughout the entire 
organisation. This article seeks to analyse one aspect of the engagement process within Historic Ormiston House, an established historic house. In so doing, it questions how a research project itself can act effectively as part of this engagement process, while assisting in the development of meaningful relationships with communities.

\section{Historic Ormiston House: A location of national historic significance}

Historic Ormiston House has been variously known as 'Ormiston', 'Ormiston House', 'Ormiston Estate', 'Ormiston Plantation', 'Ormiston House Estate' and 'Ormiston Point Estate'. ${ }^{31}$ Approximately a forty-minute drive from the Brisbane CBD, Historic Ormiston House is situated on the edge of Moreton Bay and is an important Redland City tourist attraction. ${ }^{32}$ The house and property are currently listed on the Queensland Heritage Register (place ID 600775) due to the fulfilment of several different criteria, including 'rare aspect[s] of Queensland's history', the property's association with significant historical figures and its importance in developing greater understandings of Queensland history. ${ }^{33}$ A variety of owners, employees and tenants have lived on the property throughout its time as a private residence, and the property holds relevance not only for local and state history, but also national history. The history of the property also reveals unique connections between colonial Queensland and international locations, such as Europe and the United Kingdom, within the context of agricultural industries and development.

The building currently known as 'Ormiston House' was part of the plantation originally known as 'Ormiston', and was built by the Honourable Captain Louis Hope, who was a captain in the Coldstream Guards, a member of Queensland's first Legislative Council, and a prominent figure in Australia's commercial sugargrowing industry. ${ }^{34}$ Building of the slab hut on the property commenced in 1853 , and building of the main house was completed by $1865 . .^{35}$ Hope was well recognised for his involvement in the sugar cane industry, and was the first person in Australia to successfully grow and produce commercial sugar, proving that sugar was a viable commercial industry in Australia by 1864 due to the results from his experiments at the Ormiston plantation. ${ }^{36}$ It is for this reason that the Historic Ormiston House property has become such an iconic landmark. Indeed, as a result of Hope's involvement in the establishment of a commercial sugar industry in Australia, the Ormiston property was recognised as the birthplace of Australia's commercial sugar industry. ${ }^{37}$ Hope and his family lived at Ormiston for some years, eventually leaving the property and departing for the United Kingdom in 1882.38

A number of different tenants leased Ormiston House between 1883 and 1913; following this period of tenancy, the house and property was purchased by John Arthur Macartney. ${ }^{39}$ Notwithstanding the slowly diminishing size of the estate as sections of the property were sold, and Macartney's own status as a pastoralist, horseman and fellow of the Royal Geographical Society, the association between the Ormiston property and 'Captain Louis Hope, a scion of the house of Hopetoun', was still well remembered. ${ }^{40}$ Upon Macartney's death in 1917 , the Ormiston property passed to his daughter, Flora Macartney, who lived on the property until her own death in $1955 .{ }^{41}$ After being maintained by other members of the Macartney family following Flora's death, the property was sold to the Carmelite 
Community in $1959 .{ }^{42}$ Despite the various owners and residents who have lived on this property, it nonetheless still remains well recognised as the birthplace of Australia's sugar industry, and the former home of Hope, who has been recognised as 'the father of the new [sugar] industry'. ${ }^{43}$

When the restoration of Ormiston House commenced in 1965, restoration efforts were undertaken by a small number of volunteers. In 1967, the Ormiston House Restoration Committee was formed to coordinate these efforts, with the intention of not only restoring the house, but opening it to the public. While the house and property are owned by the Carmelite Community, Historic Ormiston House is currently run and maintained by the Ormiston House Friends and Advisers Committee, and a Carmelite Liaison Officer (Monastery Representative) on behalf of the Carmelite Community. Throughout this history of Ormiston House and its period of restoration, there has been an ongoing legacy of Hope and his contributions to the sugar industry. Yet the other owners, employees and tenants of the house also have their own equally important connections to local, state and national history. Indeed, the local surrounds of the suburb itself evince a deep connection to the historical landscape and events that have occurred throughout Ormiston House's existence. Nonetheless, significantly less attention was drawn to these aspects of the property's history in the existing literature. While there was general acknowledgement of Hope and Macartney as property owners in this literature, there existed little research that assessed the significance of Historic Ormiston House in terms of other residents and employees, and the property's connection to the local area. It was the acknowledgement of this discontinuity in knowledge that led to the unique way in which research was combined within engagement processes at Historic Ormiston House.

\section{Community-driven engagement and Historic Ormiston House}

When approaching engagement possibilities at Historic Ormiston House, the engagement zone as both a conceptual and physical space was considered carefully. As Bryony Onciul suggests, museums 'create engagement zones' when they 'work with communities'. ${ }^{44}$ This concept 'emphasizes the importance of inter- as well as crosscultural relations, the sharing of on- and off-stage culture, and the potential risks, costs, and benefits' to those involved in engagement processes. ${ }^{45}$ In developing this concept, Onciul suggests the involvement of both the community and the museum in this engagement zone can lead to various potential outcomes, such as an adaption of museum practices, changes to policies, the development of new exhibits or programmes and the instigation of community members volunteering for positions at the museum. ${ }^{46}$ As such, the involvement of the community and Historic Ormiston House in the engagement zone via a research project held the potential to provide many valuable heritage-related opportunities, such as increasing and preserving knowledge. As a result, this also enabled the possibility of beneficial engagement by encouraging the involvement of the public with Historic Ormiston House, a strategy that can lead to positive outcomes such as social benefits and ongoing involvement with the property.

At Historic Ormiston House, the development of new exhibits, displays and learning resources for volunteer staff and the community was seen to be a particularly relevant outcome in light of existing knowledge relating to the history of Ormiston House and its residents. Nonetheless, while this would be a beneficial 
outcome which would hold specific importance for the goals of Historic Ormiston House as an HHM, the Ormiston House Friends and Advisers Committee (hereafter 'Friends and Advisers Committee') wanted to ensure this process would provide the opportunity for positive, ongoing engagement, rather than becoming a process that would lead to a one-sided outcome, solely beneficial for Historic Ormiston House. ${ }^{47}$ Positive museum engagement can lead to reciprocal relationships between the museum and the community, ${ }^{48}$ and these relationships can be actively nurtured to ensure that museums and HHMs meaningfully connect with communities in an ongoing capacity. In so doing, visitors can be provided with the opportunity, place and purpose to be active participants in the engagement process rather than passive consumers of knowledge. Within this context, museum engagement can become far more than increased visitor numbers, and can instead provide numerous benefits to the community, including a 'capacity for reflection, restoration, and well-being; affirmation of one's sense of self; and increased feelings of connectedness to community and culture'. ${ }^{49}$

Despite the various models and approaches that exist when considering engagement, all attempts to encourage positive engagement require a strong basis on which to develop these relationships. At Historic Ormiston House, developing an inclusive approach to accessibility was crucial. Visitors were also provided with multiple ways to engage with information, volunteer guides and Historic Ormiston House as an historic site. ${ }^{50}$ This was an adaptive, growing process that was updated continually and changed to reflect the needs of the community. ${ }^{51}$ Nonetheless, while this provides an essential basis for engagement, and can help ensure the viability of other avenues of engagement, accessibility does not necessarily lead to positive, ongoing engagement. ${ }^{52}$ The reciprocal relationships surrounding engagement must still be nurtured actively to ensure that museums and historic house museums meaningfully connect with communities in an ongoing capacity.

At Historic Ormiston House, the decision was made to use a research project as one part of the overall engagement process. An oral history project was chosen and developed in order to fulfil both engagement and research aims. This decision was based on a number of factors, including what Historic Ormiston House was able to facilitate as a not-for-profit organisation, and the types of projects in which the community was willing and able to be involved. The Ormiston House Oral History Project centred around those who had lived in Ormiston House (both owners and employees) and those who had regularly visited Ormiston House during its time as a private residence. Those who fell into these categories were identified as the project cohort. All interviews were conducted on a volunteer basis by an historian trained in the use of oral history, and development of the project aims was completed in consultation with members of the Friends and Advisers Committee. During the first round of project interviews, fourteen interviews were conducted, although this number increased during subsequent rounds of interviews. A new series of interviews that relate to this project is also currently being conducted by the same historian (now the Historic Ormiston House Resident Historian, a role undertaken in a voluntary capacity).

While archival research is actively conducted at Historic Ormiston House, the oral history methodological process provided an opportunity for Historic Ormiston House to engage with the community, and for the community to likewise engage with Historic Ormiston House as an historic house museum. In so doing 
relationships were developed between participants in the project and Historic Ormiston House. Visitors involved in the project became active participants in the engagement process and developed an ongoing relationship with Historic Ormiston House that has delivered meaningful benefits to participants, such as increased involvement with Historic Ormiston House as an HHM and community organisation, and increased understanding of each participant's place within local history. As an oral history project, the research also provided the valuable opportunity to record narratives of local history that would otherwise have remained undocumented, a topic which is becoming increasingly important in Redland City. ${ }^{53}$

In approaching the early research in the project, some local community members were attending a commemorative open day held at Historic Ormiston House. During this visit, they expressed an interest in sharing knowledge about historical events pertinent to the house and its residents. The project was subsequently developed by the historian in consultation with the Friends and Advisers Committee, which included the need to secure funding for equipment and establish a project framework. Other potential participants soon became aware of the project via a 'snowball' effect ${ }^{54}$ within the initial interviewees' and Historic Ormiston House volunteers' personal networks, and this provided a basis for early research in the project. The research aims for the project sought to develop an understanding of life on the Ormiston estate during its time as a private residence, to gain a deeper understanding of how the house and property had changed over time and to develop an understanding of the importance of the property as an historic site within the local community and for those who had lived on the property or visited the property as a private residence.

When developing this oral history project, aspects of a community-driven engagement model were utilised. A community-driven engagement model typically involves other community groups or greater collaboration between the public, the local community and the organisation. ${ }^{55}$ Within the context of Historic Ormiston House, the use of a community-driven model also included understanding the goals and needs of participants involved in the project, involvement of all those who expressed a desire to participate and accomplishing 'results of mutual benefit for all involved. ${ }^{56}$ Each model of engagement has its own benefits and limitations, and some models - such as a top-down approach ${ }^{57}$ - will not necessarily be effective for all situations. As Corinne Perkin suggests, museum outreach projects can have a 'natural tendency' to conform to a top-down model; however, this can present various challenges, including a reduction in the development of 'sustainable collaborative partnerships' between communities, museums and other organisations. ${ }^{58}$ Indeed, as Onciul notes, 'current models and terminology do not fully encapsulate the complex realities of engagement in practice. ${ }^{59}$

Drawing on a particular model does not ameliorate all potential problems and challenges that may arise throughout the process, as 'the realities of engagement are much more untidy and fluid than any model or category can account for'. ${ }^{60}$ The use of a community-driven model within this situation is not without risks, and it was important that Historic Ormiston House as an historic house museum remained cognisant of marginalised groups and individuals who may not necessarily be heard in a solely community-driven project. ${ }^{61}$ Nonetheless, drawing on aspects of a suitable engagement model at Historic Ormiston House provided a baseline approach from which the project could be built with the intended outcome of 
positive engagement that could benefit both the community and Historic Ormiston House. While the project did involve research aims that, if successful, would benefit Historic Ormiston House in terms of the new knowledge gained, the project also provided Historic Ormiston House with the opportunity to engage with participants in an active and ongoing way.

Collaboration is an essential aspect of the community-driven engagement process that was drawn upon in the project at Historic Ormiston House. In some oral history projects, interviewees participate in pre-interview screening and the interview, but subsequently have little contact with the interviewer or related organisation once the interview has concluded. ${ }^{62}$ Indeed, some interviewees in the Ormiston House Oral History Project expressed concern regarding this structure, as they had previously been interviewed for projects of this nature. ${ }^{63}$ Yet the antithesis is also possible, wherein the relationships developed during the project do not necessarily cease upon completion of the interview or project. ${ }^{64}$ The structure of the project at Historic Ormiston House involved a collaboration of local knowledge and memory (via participants) with historical expertise and heritage expertise (via the historian and Historic Ormiston House). This positive involvement of local community members with the historic house museum can in turn contribute to a beneficial approach to engagement. ${ }^{65}$

During the Ormiston House Oral History Project, the benefits of this approach became apparent when participants were actively encouraged to return as visitors to Historic Ormiston House in order to see the development of new displays and events that had been developed as a result of the research. This contributed to the development of an environment that allowed meaningful engagement and relationships to grow with those community members involved in the project. Nonetheless, without ongoing collaboration, any benefits achieved as a result of this process may quickly diminish. Indeed, engagement can frequently cease once a project or campaign has concluded. ${ }^{66}$ In contrast to this approach, at Historic Ormiston House volunteer staff specifically acted to build on the engagement and relationships established during the project. In this way Historic Ormiston House as an historic house museum became a space with which participants could identify, and provided them with a longitudinal opportunity to be active participants, rather than passive consumers of information and displays.

While the oral history interviews conducted during the Ormiston House Oral History Project contributed to the environment required to begin developing positive engagement and relationships, it nonetheless necessitated that a balance be found between the aims of Historic Ormiston House and the needs of the community throughout the project. At times, this led to additional research meetings or interviews with participants, particularly if they had a particular interest they wanted to pursue, or further information they wanted to provide. Not all these additional meetings were central to the sole concern of the original project, yet they did influence the development of further research that developed from the original research aims and still related to the history of the property. As Donald Ritchie and David Mould both discuss, this is an aspect of the oral history process that can produce positive outcomes when utilised appropriately. ${ }^{67}$ Mould notes that allowing the interviewee to digress from the interview questions or structure can be useful and, as Ritchie suggests, solely focusing on the originally intended research questions at the expense of all other topics can in fact be counter-productive. 
Asking questions or listening to discussions that are beyond the purview of the original research aims and 'immediate research interests' requires careful consideration. ${ }^{68}$ Within this context, it is possible to view the difficulties faced when drawing on aspects of a community-driven engagement model. When critically assessing the way in which this model influenced the use of this research project within the engagement processes at Historic Ormiston House, it is clear there was a need to balance the obligations of the historic house museum and the needs of the community. Historic house museums may not necessarily have the required funds or personnel to conduct unlimited projects; indeed, many HHM are dependent on volunteer staff and lack funding opportunities. ${ }^{69}$ While more grants and funding opportunities are gradually becoming available to museums and small museums, many HHMs are ineligible to apply, as they are privately owned properties or do not fulfil eligibility requirements. ${ }^{70}$ As a result, funding is a crucial factor when decisions regarding potential projects are made, thereby highlighting the need to remain aware of the needs of both the community and the historic house museum itself. This is particularly relevant for organisations such as HHMs, which may not have the required funds to continue or commence a project - whether that be a research project, such as the one conducted at Historic Ormiston House, or other measures and projects undertaken as part of the engagement process.

While Historic Ormiston House as an historic house museum may not have the capacity to pursue every research opportunity that arises, appropriate management of this scenario can still provide the opportunity to encourage community members' active participation in historic sites. Historic house museums do have the ability to assist communities to ensure that historically valuable knowledge and information are maintained for the future. Certainly, it has traditionally been accepted that the role of museums and historic sites is to 'gather, preserve and study objects' ${ }^{71}$ Nonetheless, growing and adapting from this traditional purpose, and approaching this research project from a collaborative point of view, allowed participants in the Ormiston House Oral History Project to develop a sense of ownership. Indeed, this process can provide the community with an opportunity to take ownership of their history and memories.

\section{Ownership and engagement: Benefits for Historic Ormiston House and visitors}

Utilising an oral history project as a method of engagement at Historic Ormiston House has allowed the organisation to fulfil its role to "preserve and display ${ }^{, 72}$ knowledge, while also allowing visitors to engage actively with Historic Ormiston House as an historic site. At the very base level of engagement, the project encouraged interviewees' involvement with Historic Ormiston House. Prior to participating in the project, some interviewees had not visited Historic Ormiston House for more than two decades, and did not have active intentions to revisit the property. ${ }^{73}$ After participating in the project, some interviewees have since returned to visit the property on multiple occasions. Some participants, such as Dianne Waters, who lived and worked on the property, have returned to visit Historic Ormiston House with multiple generations of her family. Waters' children, grandchildren and great-grandchildren held a desire to learn about the place where 
Waters had lived and worked, and Waters also wanted her family to understand the personal importance of the house and property to herself. ${ }^{74}$

This engagement of Waters and her extended family is a valuable outcome for far more significant reasons than simply increased visitor numbers. Through this process, Waters' histories were recognised as valuable by a wider audience than just herself and her family. Indeed, recognition of these often under-valued narratives is crucial to the community-driven style of engagement model used alongside this project. In this way the importance of Historic Ormiston House as an historic site for Waters was valued and acknowledged, which in turn gave Waters a space in which to potentially redevelop feelings of connectedness with the site, and of ownership surrounding her experiences and history. As a result this allowed for increased opportunities for Waters to become engaged with the site, even after the considerable amount of time that had passed since she had lived on the property.

Beyond the initial increase in visitation by project participants, the oral history project has also led to benefits for Historic Ormiston House as an historic house museum. The project provided Historic Ormiston House with one method to cultivate and preserve historical knowledge for the benefit of future learning a process that is an axiomatic, albeit traditional, role of museums. ${ }^{75}$ This preservation of knowledge is particularly relevant to local historic sites, which aim to 'curate the stories of local personalities, heroes, and the settings of events that mould regional history. ${ }^{76}$ In preserving this knowledge, Historic Ormiston House thus facilitated the collection of 'the reminiscences that would otherwise be lost'. ${ }^{77}$ While it is important to carefully remain cognisant of the 'fallibility of human memory', these oral histories can still become a valuable record of local history and community perceptions of Historic Ormiston House as an historic site, particularly when used in consultation with relevant archival research. ${ }^{78}$ This methodology holds value and potential if used as a method or tool within the engagement process.

The gathering and development of knowledge that occurred during the Ormiston House Oral History Project allowed the existing understanding of events pertaining to Historic Ormiston House and its surrounding area to be developed. It also allowed the historical displays at Historic Ormiston House to be developed and strengthened, which increased the understanding of local history from a collective community perspective. This represents a distancing from the traditional top-down, institution-led historiographical approach. The approach undertaken at Historic Ormiston House allowed visitors to become engaged in the process of knowledge preservation and development via participation in the oral history project, including active engagement in project outcomes such as lectures, presentations and displays. The process thus became meaningful for interviewees as they became active participants in Historic Ormiston House as an historic site via their involvement in the oral history project.

As the participants in the Ormiston House Oral History Project became actively involved in the research as interviewees, the content of the interviews began to influence ongoing research outcomes at Historic Ormiston House. In so doing the tours, lectures and historical displays offered at the property were imbued with the understandings developed as a result of the interviews. The project participants, who had all previously visited the Historic Ormiston House, rapidly became far more than passive consumers of knowledge. These visitors were no longer attending Historic Ormiston House only with the intention of consuming an historical 
display; involvement in the research project provided these participants with the opportunity to contribute to the development of knowledge at Historic Ormiston House as active participants. This reciprocity and involvement of both Historic Ormiston House volunteers (as tour guides) and the public (as visitors) in this process is a crucial aspect of this engagement process. ${ }^{79}$ In this case study, this process was facilitated by the Oral History Project, simultaneously providing benefits to both the community and Historic Ormiston House.

Moving beyond contributions to knowledge, this process also allowed project participants and the wider community to develop a sense of active ownership surrounding their own histories and their connection to Historic Ormiston House. Mary Brown, a participant in the project, commented that being at Historic Ormiston House 'really brings back memories. Nice memories. Very special. I'm just lucky and I'm thankful I had the chance to be here. It's always been very special to me but I never thought that I'd be showing things and be talking about it ${ }^{\prime}{ }^{80}$ This reveals not only Brown's ownership of her memories and history, but provides acknowledgement of the place of these memories within the broader historical narrative of the area and a reflection of the shared aspects of these memories. As part of the overall engagement process, these outcomes were considered particularly valuable by Historic Ormiston House. Participants in the project were being provided with the space and opportunity to develop a sense of ownership around their own histories and narratives, which simultaneously were deeply intertwined with the broader narrative of the historic site and the surrounding area.

In addition to the sense of ownership developed during the project interviews, it was also possible to encourage further engagement and a recognition of ownership through post-project outcomes. Ritchie observes that providing access to content developed from a project, such as 'interviews ... maps, photographs [and] documents' can assist in providing this 'sense of "ownership" of the project to the community itself'. ${ }^{81}$ While Ritchie does suggest providing access to such outcomes via a website, this was achieved at Historic Ormiston House by providing access to such outcomes on the property itself. Not only did the medium of a website not meet the needs of the visitor demographic at Historic Ormiston House at the time, but engagement with these outcomes while visiting the property provided increased opportunities to further enhance other engagement outcomes. This has variously included the development of historical lectures, adjustments to new and existing displays, adjustments to information provided during volunteer tour guide training, the development of informational brochures provided to guests, and photographic exhibitions.

The project outcomes also provided other visitors with the opportunity to connect their own narratives to the history with which they were engaging at Historic Ormiston House. Visitors gradually began to develop interactions between their personal histories and their understanding of the wider history of Ormiston House and the local area. These interactions were captured via the historian and other volunteers engaging with visitors to the property. In particular, visitors were actively invited to record their thoughts in the Historic Ormiston House Visitor Book. Some recalled they 'love the house ... used to live opposite here on a farm', ${ }^{82}$ while others drew connections between their personal narratives and Historic Ormiston House, commenting that the history and displays are 'comparable to Ormiston Hall Scotland where I was born' ${ }^{83}$ This provides a direct contrast to the 
nature of the visitor book entries recorded at Historic Ormiston House prior to the implementation of the Oral History Project as a method of engagement. It instead reflects the positioning of the individual narrative within the historical landscape that surrounds Historic Ormiston House. By engaging with the newly developed displays and tours, which were influenced explicitly by the engagement of the Oral History Project, it is revealed that visitors can receive benefits associated with learning; however, they can also engage with and become active participants within this heritage site. ${ }^{84}$ This is not limited to those involved in the Oral History Project, and instead reflects the wider benefits of the project for other guests visiting the property.

Other guests have drawn on personal connections to the property during their visit, reflecting on their memories of the property after viewing the house and displays, and interacting with volunteer tour guides. Susan Bell recalled, 'I visited and stayed here as a child, leaving good memories. Wonderful to see the house so well restored. ${ }^{85}$ Truly engaged interactions between visitors and Historic Ormiston House, such as those presented here, had not been captured prior to the commencement of the Oral History Project. Engagement with the house and its history through the visitor book and feedback from guests largely revealed visitors to the property enjoying their day and acknowledging the volunteers, with the absence of any further engagement. ${ }^{86}$ In these more recent visitor book examples, which are taken from the period during and following the Oral History Project, visitors are beginning to move beyond passive consumption towards an active consideration of their position within the space and place of the historic site. In so doing this sense of ownership and the resulting engagement can contribute to the cultivation of visitors' active engagement with the growing, living HHM, rather than simply viewing the HHM as a collection of static objects that exists ahistorically, lacking both context and relevance for the local and wider community. ${ }^{87}$ The opportunities for engagement made possible by the research outcomes of the Oral History Project are also available to all visitors, including those who were not directly involved with the project as interviewees.

It would be quixotic to suggest that an oral history project can accomplish proficient and complete engagement simply because interviewees and visitors were provided with the opportunity to engage with these research outcomes. What this case study does suggest, however, is that the oral history project and outcomes provided the necessary environment for positive outcomes of the engagement process to begin and be enhanced. What can be seen is a transition away from passive consumption of HHM displays when visiting Historic Ormiston House, and a move towards participatory engagement, particularly for those actively participating in the research project and engaging with project outcomes. ${ }^{88}$ While this does mean Historic Ormiston House must be actively aware of the ongoing engagement process throughout the research process, it is a valuable and worthwhile process, as it allows visitors to embrace the histories and narratives present at Historic Ormiston House as an historic site, rather than simply consuming the content without active consideration or participation.

The ongoing development of engagement at Historic Ormiston House has allowed visitors to embrace the histories of the site while actively developing their own personal connections to the broader historical narrative that is intertwined with Historic Ormiston House as an historic house museum. This has also laid the groundwork for ongoing engagement, with the establishment of these relationships 
continuing beyond the oral history interview, allowing Historic Ormiston House to continue engaging with the community beyond the conclusion of the project. Nonetheless, it was recognised early in the project that if the Oral History Project was to be successful as a method of engagement, Historic Ormiston House as an HHM must also reposition itself, and create a social relevance from this project for the community. ${ }^{89}$ In so doing, this oral history project has not only provided a space for engagement to visitors, but it has transformed Historic Ormiston House itself into an 'engagement-ready' heritage space that is reshaping itself to remain relevant while still fulfilling the expected role of an historic house museum.

Throughout this project, Historic Ormiston House was gradually repositioned from an HHM that displayed a restored house and objects to the public, to instead become a place of shared heritage, memories and history. While the status of Historic Ormiston House as an historic site is inherently crucial to its role, the values of Historic Ormiston House as an HHM began to develop throughout the project. While the Historic Ormiston House volunteers retained a commitment to preserving and sharing knowledge, the development of the oral history project allowed Historic Ormiston House to be repositioned, and a balance was sought between the traditional obligations of an historic house museum and creating a new social relevance. ${ }^{90}$ In so doing this allowed Historic Ormiston House and its volunteers to continually grow in their roles of facilitating engagement with the community. In creating this social relevance, the engagement process was not only made accessible to the community, but it provided ongoing opportunities whereby visitors were able to become actively involved with Historic Ormiston House. When conflated with the context of the Oral History Project, this provided visitors with the opportunity to become far more than passive consumers of knowledge. Not only can guests be active participants when they interact with tour guides and displays, but they can also be actively involved in the development of this knowledge. This can allow visitors to encourage a sense of ownership surrounding this heritage and their personal historical narratives, and can provide visitors with an opportunity to actively embrace this heritage and its ongoing importance to the community.

\section{Conclusion}

Community involvement in the oral history project at Historic Ormiston House is an active, ongoing process that involves both the researcher and the interviewees. It also involves other visitors to Historic Ormiston House, such as those who were not directly involved in the original project, but nonetheless have taken up the opportunities offered to become active participants in the historic site. While many of these benefits are linked to those with a direct connection to the project, this case study demonstrates the benefits can be extended to the wider community as a result of the development of a meaningful and ongoing engagement process. The Ormiston House Oral History Project is one part of a multi-faceted approach to engagement. An oral history project alone cannot suffice when attempting to encourage participatory engagement; however, it can complement other engagement methods and can provide opportunities to enhance participatory aspects of engagement. In this way, the Oral History Project, while acting as a stand-alone component within the engagement process at Historic Ormiston House, is also 
connected to the wider development of relationships between Historic Ormiston House as an historic house museum and the community.

When HHMs engage with communities, there is a response of further engagement and participation as individuals see the development of displays as a living, growing body of knowledge. This holds potential benefits, even for those who are not directly involved in the project. When visitors engage with the knowledge shared as a result of the oral history process, they receive benefits associated with learning; however, they can also engage with and become active participants within the historic site. These outcomes hold importance for both Historic Ormiston House as an HHM and for the community. Indeed, by using oral histories as a method of engagement, community engagement can become an active, participatory process that can continue beyond the duration of the project.

Historic house museums and historic sites can learn, educate and represent the past while contributing to an active engagement with heritage and historical narratives. This engagement is strengthened by the sharing of historical knowledge, and an enhanced understanding of shared histories within the context of an inclusive and engaged museum. An oral history project such as the one conducted at Historic Ormiston House represents a tangible process that can be utilised within a comprehensive approach to engagement that allows visitors to develop a sense of ownership surrounding the historic site and its stories. This, in turn, can enhance the development of meaningful, ongoing participation and engagement with communities.

\section{Acknowledgements}

The author wishes to acknowledge the Corporation of Discalced Nuns of the Order of Our Lady of Mount Carmel (the present owners of Historic Ormiston House), which continues to open this historic house to the public with a desire to share its history, beauty and peacefulness with the local and wider community, and which has supported the ongoing research regarding the history of the property. The author also wishes to acknowledge past and present members of the Ormiston House Friends and Advisers Committee, who have also supported the ongoing development of research regarding the history of the property. Further, the author wishes to acknowledge the Corporation of Discalced Nuns of The Order of Our Lady of Mount Carmel (the present owners of Historic Ormiston House), the Ormiston House Friends and Advisers Committee, and the Carmelite Liaison Officer (Monastery Representative), who provided in-kind support by allowing the Historic Ormiston House premises to be used during the Ormiston House Oral History Project. The Ormiston House Oral History Project was supported by the Redland City Council Grants and Sponsorship Program: Councillors' Small Grants 2012-13, to enable the supply of equipment for the project.

\section{Notes}

1 All names of participants in the Ormiston House Oral History Project are pseudonyms.

2 Syd Lee, M.A. Taylor and Sylvia Webster, in Historic Ormiston House visitor book, 1998-2007, Historic Ormiston House Research Library.

3 'New monastery for Ormiston', Courier-Mail, 25 September 1959, 11; Sister Katherine, 'History of Ormiston House since we purchased it', email to M. O’Driscoll, 23 May 2013. 
4 ibid.

5 ibid.

6 Margaret O’Driscoll, 'Annual report delivered to Carmelite Community and volunteers', 2011.

7 For example, Historic Ormiston House and its volunteers have received nominations and/ or awards in the following programmes and categories: Gallery and Museum Achievement Awards; Museums \& Gallery Services Queensland Gallery and Museum Achievement Awards (Organisations); Redlands on Moreton Bay Tourism Awards (Heritage and Cultural Tourism); Redlands Tourism Award (Outstanding Contribution by an Individual); Redlands Tourism Award (Outstanding Contribution to Tourism); Redlands Tourism Award (Special Event or Festival); Redlands Tourism Award (Tourist Attraction); Redlands Tourism Awards (Historic House); Volunteering Redlands Greg Cook Volunteering Recognition Award.

8 Bryony Onciul, Museums, heritage and Indigenous voice: Decolonising engagement (New York: Routledge, 2015), p. 71.

9 Michele Everett and Margaret Barrett, 'Benefits visitors derive from sustained engagement with a single museum', Curator: The Museum Journal 54(4) (2011), 432, 441; Onciul, Museums, heritage and Indigenous voice, pp. 71-2.

10 See, for example, a growing emphasis on museum engagement at events coordinated by Museums \& Galleries Queensland, one of the most significant industry bodies for museum professionals in Queensland: Museums \& Galleries Queensland, 'M\&G QLD Past Events', 2017, http://www.magsq.com.au/cms/page.asp?ID=5129, accessed 3 October 2017.

11 Everett and Barrett, 'Benefits visitors derive from sustained engagement', 432; Bryony Onciul, 'Community engagement, curatorial practice, and museum ethos in Alberta, Canada', in Viv Golding and Wayne Modest (eds), Museums and communities: Curators, collections and collaboration (London: Bloomsbury, 2013), p. 92.

12 Susan Ashley, “Engage the world”: Examining conflicts of engagement in public museums', International Journal of Cultural Policy 20(3) (2014), 262; Onciul, Museums, heritage and Indigenous voice, p. 71. For further examples of working definitions of museum engagement, see Everett and Barrett, 'Benefits visitors derive from sustained engagement', 432, 442; Peter Welsh, 'Re-configuring museums', Museum Management and Curatorship 20(2) (2005), 106.

13 Everett and Barrett, 'Benefits visitors derive from sustained engagement', 432; Welsh, 'Re-configuring museums', 106.

14 Juli-Anna Aerila, Marja-Leena Rönkkö and Satu Grönman, 'Field trip to a historic house museum with preschoolers: Stories and crafts as tools for cultural heritage education', Visitor Studies 19(2) (2016), 144; Linda Young, Historic house museums in the United States and the United Kingdom: A history (Lanham, MD: Rowman \& Littlefield, 2017), p. 256; Deborah Ryan and Frank Vagnone, 'An anarchist guide to historic rooms and house museums', in Culture: New ideas, minor voices, and topics on the margins - ARCC 2013: The visibility of research, Conference Proceedings (2013), p. 165.

15 Martha Morris, Managing people and projects in museums: Strategies that work (Lanham, MD: Rowman \& Littlefield, 2017), p. 22; Walter Crimm, Martha Morris and Carole Wharton, Planning successful museum building projects (Lanham, MD: AltaMira Press, 2009), p. 236.

16 Amareswar Galla, 'El museo inclusivo', Museos. es: Revista de la Subdirección General de Museos Estatales 9 (2013), 40. 
17 See, for example, Kristiina Kumpulainen, Marianna Karttunen, Leenu Juurola and Anna Mikkola, 'Towards children's creative museum engagement and collaborative sensemaking', Digital Creativity 25(3) (2014), 233; Paul Barron and Anna Leask, 'Visitor engagement at museums: Generation Y and "Lates" events at the National Museum of Scotland', Museum Management and Curatorship 32(5) (2017), 473, 482-3; Ealasaid Munro, "People just need to feel important, like someone is listening": Recognising museums' community engagement programmes as spaces of care', Geoforum 48 (2013), 56-7, 61; Laurajane Smith, 'Visitor emotion, affect and registers of engagement at museums and heritage sites', Conservation Science in Cultural Heritage 14(2) (2014), 125-6.

18 William Alderson, 'Foreword', in Sherry Butcher-Younghans, Historic house museums: A practical handbook for their care, preservation, and management (New York: Oxford University Press, 1993), p. v; Linda Young, 'Major case study: Welcome to our house satisfying visitors to the historic house museum', in Ruth Rentschler and Anne-Marie Hede (eds), Museum marketing: Competing in the global marketplace (Burlington, MA: Butterworth-Heinemann, 2007), 134.

19 Sherry Butcher-Younghans, Historic house museums: A practical handbook for their care, preservation, and management (New York: Oxford University Press, 1993), pp. 184-5; Deepak Chhabra, Sustainable marketing of cultural and heritage tourism (Abingdon, Oxon: Routledge, 2010), p. 111.

20 Jane Merritt and Julie Reilly, Preventative conservation for historic house museums (Plymouth: AltaMira Press, 2010), pp. 9-10.

21 Ryan and Vagone, 'An anarchist guide to historic rooms and house museums', 165.

22 ibid.; Chhabra, Sustainable marketing, 112.

23 Young, 'Major case study: Welcome to our house', 133.

24 ibid., 133-4.

25 Chhabra, Sustainable marketing, 113.

26 Gabrielle Rappolt-Schlichtmann and Samantha Daley, 'Providing access to engagement in learning: The potential of universal design for learning in museum design', Curator: The Museum Journal 56(3) (2013), 307; Laurajane Smith and Emma Waterton, Heritage, communities and archaeology (London: Bloomsbury, 2009), p. 112.

27 Chhabra, Sustainable marketing, 114.

28 For literature that addresses the unique position of historic house museums within the museum sector, see, for example Hedvig Mårdh, 'Re-entering the house: Scenographic and artistic interventions and interactions in the historic house museum', Nordisk Museologi 1 (2015), 25-39; Gustaf Leijonhufvud and Annette Henning, 'Rethinking indoor climate control in historic buildings: The importance of negotiated priorities and discursive hegemony at a Swedish museum', Energy Research \& Social Science 4 (2014), 117-23; Merritt and Reilly, Preventative conservation for historic house museums; Young, Historic house museums; Rebekah Beaulieu, Financial fundamentals for historic house museums (Lanham, MD: Rowman \& Littlefield, 2017).

29 See, for example Kim Christensen, 'Ideas versus things: The balancing act of interpreting historic house museums', International Journal of Heritage Studies 17(2) (2011), 153-68; Maria Adinolfi and Mattijs van de Port, "Bed and throne: The "Museumification" of the living quarters of a Candomblé priestess', Material Religion 9(3) (2013), 282-303; Christina Hodge and Christa Beranek, 'Dwelling: Transforming narratives at historic house museums', International Journal of Heritage Studies 17(2) (2011), 97-101; Isabelle Vinson, 'Editorial', Museum International 53(2) (2001), 3; Giovanni Pinna, 'Introduction to historic house museums', Museum International 53(2) (2001), 4-9; Deborah Ryan and 
Frank Vagnone, 'Reorienting historic house museums: An anarchist's guide', in $R e$ disciplining: The rise, fall and reformation of the disciplines history, theory, historiography, and future studies: ARCC/EAAE 2014: Beyond architecture: New intersections \& connections, CONFERENCE PROCEEDINGS, 2014, pp. 97-8; Rosanna Pavoni, 'Towards a definition and typology of historic house museums', Museum International 53(2) (2001), $16-21$.

30 See Aerila, Rönkkö and Grönman, 'Field trip to a historic house museum with preschoolers', 144-55; Alexandra Chan, 'Translating archaeology for the public: Empowering and engaging museum goers with the past', International Journal of Heritage Studies 17(2) (2011), 169-89; Linda Young, 'Is there a museum in the house? Historic houses as a species of museum', Museum Management and Curatorship 22(1) (2007), 59-77; Catherine Howett, 'Grounds for interpretation: The landscape context of historic house museums', in Jessica Donnelly (ed.), Interpreting historic house museums (Walnut Creek, CA: AltaMira Press, 2002), 126; Janet Sinclair, 'Expanding family access and engagement in an historic house museum', in Juilee Decker (ed.), Engagement and access: Innovative approaches for museums (Lanham, MD: Rowman \& Littlefield, 2015), 61-70.

31 Cameron Brothers (auctioneers) and R.A. Hamilton and James (surveyors), 'Ormiston Estate' (Brisbane: H.T. James Lithographers, 1918), Record Number 21104989870002061, John Oxley Library, State Library of Queensland; Cameron Brothers (auctioneers) and J. Wynne Townson (surveyor), 'Ormiston Point Estate: On the Cleveland Railway' (Brisbane: Will H. Clarke and A.M. McLaren, 1919), Record Number 21188580250002061, John Oxley Library, State Library of Queensland; 'Memorial to sugar pioneers: To be built on Ormiston Plantation', Courier-Mail, 29 June 1935, 14; Queensland Heritage Register, 'Ormiston House Estate', Queensland Government, https://environment.ehp.qld.gov.au/ heritage-register/detail/?id=600775, accessed 4 September 2017; Historic Ormiston House, 'Home', http://ormistonhouse.org.au, accessed 12 September 2017.

32 Redland City Council, Redlands visitor guide, 2016, p. 10.

33 Queensland Heritage Register, 'Ormiston House Estate'.

34 A.A. Morrison, 'Hope, Louis (1817-1894)', in Australian dictionary of biography (Melbourne University Press, 1972), http://adb.anu.edu.au/biography/hope-louis-3791, accessed 4 September 2017; Queensland Parliament, 'Members of the First Parliament 1860', https://www.parliament.qld.gov.au/members/former/first-parliament, accessed 15 September 2017.

35 Claudius Whish, 'Claudius Buchanan Whish diaries 1855-1906', Reference Code OM6533, John Oxley Library, State Library of Queensland.

36 'Telegraphic', Brisbane Courier, 16 September 1864, 2; 'Cultivation of sugar (from The Guardian)', Queensland Times, Ipswich Herald and General Advertiser, 28 September 1864, 4; John Kerr, 'Establishing Australia's sugar industry at Ormiston: A Hope and a Whish', Royal Historical Society of Queensland Journal 17(8) (2000), 337.

37 Morrison, 'Hope, Louis'; Patrick Briody, 'Ormiston House', Australian Sugar Journal December (1985), 349.

38 'Monday 9th October', Brisbane Courier, 20 September 1882, 8; 'Departures - October 19', Australian Town and Country Journal, 28 October 1882, 36; 'R.M.S. Verona', Argus, 16 December 1882, 9.

39 'For royal guest's country visit: Picturesque Ormiston House', Telegraph, 26 September 1934, 17.

40 H.J. Gibbney, 'Macartney, John Arthur (1834-1917)', in Australian dictionary of biography (Melbourne University Press, 1974), http://adb.anu.edu.au/biography/macartneyjohn-arthur-624, accessed 4 September 2017; Henzell and Cameron Estate Maps, 'Plan 
of the valuable properties of the Honble. Louis Hope' (Brisbane), Record Number 21112815920002061, John Oxley Library, State Library of Queensland; Cameron Brothers (auctioneers) and R.A. Hamilton and James (surveyors), 'Ormiston Estate'; Cameron Brothers (auctioneers) and J. Wynne Townson (surveyor), 'Ormiston Point Estate'; 'Ormiston Estate', Morning Bulletin, 19 July 1913, 6.

41 Gibbney, 'Macartney, John Arthur'; 'It's older than the State ... historic home is sold by family', Courier-Mail, 22 January 1959, 13.

42 ibid.; Sister Katherine, 'History of Ormiston House'.

43 'Queensland Parliament record of proceedings (Hansard), Legislative Assembly', 5 September 1865, p. 595; Briody, 'Ormiston House', 349; “"Birthplace of the Australian sugar industry” celebrates 150 Years', in Australian Canegrower: The Flagship of the Sugarcane Industry June (2012), 5.

44 Onciul, Museums, heritage and Indigenous voice, p. 72; see also Onciul, 'Community engagement, curatorial practice', 84 .

45 ibid., 79

46 ibid.

47 Margaret O'Driscoll, 'Annual report delivered to Carmelite Community and volunteers', 2010.

48 Welsh, 'Re-configuring museums', 105-6.

49 Everett and Barrett, 'Benefits visitors derive from sustained engagement', 431.

50 Margaret O'Driscoll, 'Annual report delivered to Carmelite Community and volunteers', 2010; Margaret O'Driscoll, 'Annual report delivered to Carmelite Community and volunteers', 2011; Margaret O'Driscoll, 'Annual report delivered to Carmelite Community and volunteers', 2012.

51 ibid.

52 Rappolt-Schlichtmann and Daley, 'Providing access to engagement in learning', 307.

53 For a recent example of the increased importance of oral histories in Redland City, see: 'Redland Cultural Heritage Network meeting minutes', February 2017.

54 Patricia Leavy, Oral history: Understanding qualitative research (New York: Oxford University Press, 2011), p. 34.

55 Corinne Perkin, 'Beyond the rhetoric: Negotiating the politics and realising the potential of community-driven heritage engagement', International Journal of Heritage Studies 16(1-2) (2010), 107.

56 ibid., 108, 116; Mina Dragouni and Kalliopi Fouseki, 'Drivers of community participation in heritage tourism planning: An empirical investigation', Journal of Heritage Tourism 13(3) (2018), 2.

57 A top-down approach to engagement and museum work sees the development of projects that are driven and led by the institution itself, rather than a collaborative-based approach, which involves active collaboration between museum organisations and communities.

58 Perkin, 'Beyond the rhetoric', 107, 109, 112.

59 Onciul, 'Community engagement, curatorial practice', 83.

60 Onciul, Museums, heritage and Indigenous voice, p. 75.

61 Graham Black, 'Embedding civil engagement in museums', Museum Management and Curatorship 25(2) (2010), 136-7.

62 See David Mould, 'Interviewing', in Donna Deblasio, Charles Ganzert, David Mould, Stephen Paschen and Howard Sacks (eds), Catching stories: A practical guide to oral 
history (Athens, OH: Swallow Press, 2009), pp. 76, 82, which discusses the various stages of the oral history interview.

63 Personal communication, Jessica Stroja and Sarah Smith, 4 April 2013; Personal communication, Jessica Stroja and Jane Jones, 22 March 2013.

64 Zibiah Alfred, 'Sharing oral history with the wider public: Experiences of the refugee communities history project', in M. Kurkowska-Budzan and K. Zamorski (eds), Oral history: The challenges of dialogue (Amsterdam: John Benjamins Publishing Company, 2009), 180.

65 Perkin, 'Beyond the rhetoric', 110-11.

66 Smith and Waterton, Heritage, communities and archaeology, p. 103.

67 Mould, 'Interviewing', 81-2; Donald Ritchie, Doing oral history: A practical guide, 2nd ed. (New York: Oxford University Press, 2003), pp. 114-15.

68 ibid., p. 114.

69 Alderson, 'Foreword', v; Young, 'Major case study: Welcome to our house', 134; Patrick Butler III, 'Past, present, and future: The place of the house museum in the museum community', in Jessica Donnolley (ed.), Interpreting Historic House Museums (Walnut Creek: AltaMira Press, 2002), p. 37.

70 While Historic Ormiston House has applied for various grants and funding opportunities throughout its time as an historic house museum, there are a number of applications that cannot be submitted solely on the basis of exclusion from eligibility criteria. Inclusion in the relevant criteria would only have been possible as a small museum, rather than a privately owned historic house museum. While the issue of funding opportunities for historic house museums and small museums is an increasingly relevant topic, further discussion of this concern remains beyond the purview of this article.

71 Ruth Rentschler, 'Museum marketing: no longer a dirty word', in Ruth Rentschler and Anne-Marie Hede (eds), Museum marketing: Competing in the global marketplace (Burlington, MA: Butterworth-Heinemann, 2007), 15.

72 Historic Ormiston House, 'Home'.

73 Personal communication, Jessica Stroja and Wendy Parks, 8 March 2013.

74 Personal communication, Jessica Stroja and Dianne Waters, 9 July 2017.

75 Rentschler, 'Museum marketing', 15.

76 Teresa Bulger, 'Personalising the past: Heritage work at the Museum of African American History, Nantucket', International Journal of Heritage Studies 17(2) (2011), 136.

77 Ritchie, Doing oral history, second edition p. 46.

78 ibid., p. 30; Louise Starrm, 'Oral history', in David Dunaway and Willa Baum (eds), Oral history: An interdisciplinary anthology, $2^{\text {nd }}$ ed. (Lanham, MD: AltaMira Press, 1996), 40-1.

79 Welsh, 'Re-configuring museums', 106.

80 Mary Brown, interviewed by Jessica Stroja, 8 June 2013, Ormiston, Queensland.

81 Donald Ritchie, Doing oral history, 3rd ed. (New York: Oxford University Press, 2015), p. 249.

82 Pam Burnett in 'Historic Ormiston House visitor book, 2015-2017', Historic Ormiston House Research Library.

83 Margaret Milton in 'Historic Ormiston House visitor book, 2015-2017', Historic Ormiston House Research Library.

84 Everett and Barrett, 'Benefits visitors derive from sustained engagement', 431; Onciul, 'Community engagement, curatorial practice', 92; Bulger, 'Personalising the past', 139. 
85 Susan Bell in 'Historic Ormiston House visitor book, 2015-17, Historic Ormiston House Research Library.

86 'Historic Ormiston House visitor book, 1998-2007', Historic Ormiston House Research Library.

87 Everett and Barrett, 'Benefits visitors derive from sustained engagement', 431; Bulger, 'Personalising the past', 139.

88 While some of these benefits are clearly limited to those within the identified project cohort, the oral history process and outcomes of oral history projects can still provide benefits to other members of the public. At Historic Ormiston House, additional oral history projects are currently underway to engage with a wider cohort using the methods discussed in this case study, including a project that involves volunteers - both past and present - at Ormiston House.

89 Barbara Little and Paul Shackel, Archaeology, heritage and civic engagement: Working towards the public good (Walnut Creek, CA: Left Coast Press, 2014), p. 131; Black, 'Embedding civil engagement', 129.

90 Little and Shackel, Archaeology, heritage and civic engagement, p. 131. 